\title{
PENGGUNAAN AUDIO VISUAL UNTUK PENINGKATAN KETERAMPILAN MENYIMAK DONGENG SISWA SMP NEGERI 2 PAKISAJI MALANG
}

\author{
Suryantoro \\ Universitas Kanjuruhan Malang \\ email: suryantoro.kaka@gmail.com
}

\begin{abstract}
Abstrak
Menyimak adalah suatu proses kegiatan mendengarkan lambang-lambang lisan dengan penuh perhatian, pemahaman, apresiasi, serta interpretasi untuk memperoleh informasi, menangkap isi atau pesan, serta memahami komunikasi yang telah disampaikan sang pembicara melalui ujaran atau bahasa lisan (Tarigan, 2008:31. Agar dapat menyimak dengan baik, maka perlu dilakukan pelatihan yang intens, untuk itu diperlukan media yang tepat dalam pembelajaran menyimak Penelitian ini bertujuan untuk mendeskripsikan peningkatan keterampilan menyimak dongeng siswa SMP Negeri 2 Pakisaji Malang melalui media audio visual. Subjek penelitian, siswa kelas VII sejumlah 36 siswa. Penelitian ini menerapkan metode penelitian tindakan kelas, Classroom Action Research (CAR) model Kurt Levin, yakni menggunakan konsep yang meliputi empat komponen; (1) perencanaan (planning), (2) tindakan (action), (3) pengamatan (observing), dan (4) refleksi (reflecting). Pelaksanaan dilakukan dua siklus. Untuk menjaring data digunakan metode observasi, test, dokumentasi dan wawancara. Berdasarkan hasil penelitian, siswa mendapat nilai antara 90-100 pada siklus I sebanyak 1 siswa, pada siklus II meningkat menjadi 10 siswa. Siswa yang mendapat nilai antara 75-85 pada siklus I sebanyak 24 siswa, pada siklus II meningkat menjadi 26 siswa. Siswa yang mendapat nilai 60-70 pada siklus I terdapat 11 siswa, pada siklus II tidak terdapat lagi siswa yang mendapat nilai di bawah KKM. Secara umum dapat disimpulkan bahwa audio visual dapat meningkatkan keterampilan menyimak dongeng siswa kelas VII SMP Negeri 2 Pakisaji Malang.
\end{abstract}

Kata-kata kunci: menyimak, dongeng, media audio visual

Unsur yang termasuk sangat penting dan fundamental dalam semua interaksi adalah keterampilan untuk memahami apa yang dikatakan/ diucapkan oleh orang lain/ pembicara (Ahmadi,1990:7). Dalam kehidupan berbahasa sehari-hari, sering kita jumpai pendengarpendengar yang kurang terampil, baik dalam bahasa ibu maupun bahasa kedua; mungkin karena perhatian kurang terpusat, egosentrisme ataupun sifat kenangan lewat pendengaran yang singkat. Padahal, menurut Wilga N. Rivers (1978) dalam Ahmadi (1990:7), kebanyakan orang dewasa diperkirakan telah menggunakan waktunya dalam aktvitas komunikasi: 45\% digunakan untuk mendengarkan, $30 \%$ untuk berbicara, $16 \%$ untuk membaca, dan hanya $9 \%$ untuk menulis.

Tidak terkecuali dalam kehidupan akademik, sering kali ditemukan kasus-kasus kurangnya perhatian siswa terhadap materi pelajaran. Hasil observasi awal yang dilakukan peneliti dalam kasus pembelajaran menyimak di SMP Negeri 2 Pakisaji Malang, menunjukkan bahwa: (1) beberapa siswa cepat merasa jemu dalam kegiatan pembelajaran menyimak, (2) siswa kesulitan menemukan ide cerita atau informasi yang disampaikan, (3) beberapa siswa meninggalkan/melewatkan hal-hal penting dari cerita atau informasi yang diperdengarkan. Apalagi tidak didukung oleh media yang menarik.

Hal inilah yang melatarbelakangi peneliti untuk melakukan penelitian tentang Penggunaan Audio Visual untuk Peningkatan Keterampilan Menyimak Dongeng Siswa Kelas VII SMP Negeri 2 Pakisaji Malang. 
Bagaimanakah penerapan media audio visual dalam peningkatan ketrampilan menyimak dongeng siswa kelas VII SMP Negeri 2 Pakisaji Malang?, Bagaimakah peningkatan keterampilan menyimak dongeng siswa kelas VII SMP Negeri 2 Pakisaji Malang melalui media audio visual?

Penelitian ini bertujuan: (1) untuk memperoleh deskripsi obyketif tentang penerapan media audio visual dalam peningkatan ketrampilan menyimak dongeng siswa kelas VII SMP Negeri 2 Pakisaji; (2) untuk memperoleh deskripsi objektif tentang peningkatan keterampilan menyimak dongeng siswa kelas VII SMP Negeri 2 Pakisaji melalui media audio visual.

Menyimak adalah proses menginterpretasikan suatu ujaran/tuturan dalam bahasa Indonesia dengan cara mengombinasikan antara apa yang didengar dan apa yang sudah diketahui. Ditinjau dari segi proses verbal, mendengarkan/menyimak merupakan keterampilan yang secara fungsional "menerima" sesuatu. Sesuatu yang dimaksud adalah rangkaian "code" yang dibuat seorang pembicara melalui proses "coding" dan kemudian diterima seorang pendengar melalui proses "decoding". Proses menyimak meliputi proses fisik dan proses mental. Tiga cirri utama kegiatan menyimak, yakni memfokuskan perhatian, mengarahkan pemahaman, dan melakukan penyimpulan.

Tarigan (2008:31) mengatakan menyimak adalah suatu proses kegiatan mendengar lambang-lambang dengan penuh perhatian, pemahaman, apresiasi, serta interpretasi untuk memperoleh informasi, menangkap isi suatu pesan, serta memahami makna komunikasi yang telah disampaikan sang pembicara melalui ujaran atau bahasa lisan.

Selain memperhatikan aspek-aspek segmental yang berupa kata-kata dalam ujaran, dalam menyimak perlu diperhatikan pula aspek-aspek suprasegmental yaitu: (1) tekanan atau keras lembutnya suara, (2) jeda atau panjang pendeknya suara, (3) tinggi rendahnya suara, (4) intonasi atau naik turunnya suara, (5) ritme atau irama dalam suara. Hal ini menjadi penting untuk diperhatikan agar tujuan akhir menangkap pesan dan memahami pesan baik yang tersirat maupun pesan yang tersurat dapat dicapai dengan baik.

Tuntutan yang tinggi untuk menghasilkan seorang penyimak yang baik, rasanya mutlak perlunya kehadiran media pembelajaran yang memadai. Media berasal dari bahasa Latin merupakan bentuk jamak dari "Medium" yang secara harfiah berarti "Perantara" atau "Pengantar" yaitu perantara atau pengantar sumber pesan dengan penerima pesan. Beberapa ahli memberikan definisi tentang media pembelajaran.

Schramm (1961) mengemukakan bahwa media pembelajaran adalah teknologi pembawa pesan yang dapat dimanfaatkan untuk keperluan pembelajaran. Sementara itu, Gagne and Briggs (1975) dalam Arsyad (1997) secara implisit mengatakan bahwa media pembelajaran meliputi alat yang secara fisik digunakan untuk menyampaikan isi materi pengajaran, yang terdiri dari antara lain buku, tape recorder, kaset, video camera, video recorder, film. Slide (gambar bingkai), foto, gambar, grafik, televisi, dan komputer.

Brown (1973) mengungkapkan bahwa media pembelajaran yang digunakan dalam kegiatan pembelajaran dapat mempengaruhi efektivitas pembelajaran. Pada mulanya, media pembelajaran hanya berfungsi sebagai alat bantu guru untuk mengajar yang digunakan adalah alat bantu visual. Sekitar pertengahan abad ke-20 usaha pemanfaatan visual dilengkapi dengan digunakannya alat audio, sehingga lahirlah alat bantu audio-visual.

Sejalan dengan perkembangan ilmu pengetahuan dan teknologi (IPTEK), khususnya dalam bidang pendidikan, saat ini penggunaan alat bantu atau media pembelajaran menjadi semakin luas dan interaktif, seperti adanya komputer dan internet.

Seperti dalam tema penelitian ini, yang mengangkat dongeng sebagai materi pembelajaran menyimak, maka kehadiran 
media audio visual dalam bentuk cakram rekaman dongeng akan sangat membantu seorang guru dalam pembelajaran menyimak, sehingga dengan kehadiran media ini tidak mutlak menuntut seorang guru harus pandai mendongeng.

Dongeng berbeda dengan cerita, dongeng merupakan cerita fiksi yang bersifat imajinatif sedangkan cerita sifatnya kenyataan, Dongeng tidak terbatas pada cerita-cerita legenda saja tetapi cerita yang menyimbolkan benda mati sebagai karakter pemeran cerita, contohnya melalui alat peraga sandal yang mewah dan sederhana, dalam dongeng dapat disimbolkan sebagai orang yang sombong (sandal mewah), dan orang yang baik (sandal sederhana). Atau contoh lain seperti dongeng kura-kura dan kelinci, Ini merupakan hal yang imajinatif dan fiksi.

Dongeng adalah cerita khayal yang tidak masuk akal. Cerita dalam dongeng tak pernah terjadi dan tak mungkin terjadi. Berdasarkan isinya dongeng dapat digolongkan menjadi (a) cerita binatang; (b) cerita jenaka; (c) legenda; (d) mite, (e) sage; dan (f) parabel.

\section{METODE PENELITIAN}

Penelitian ini menerapkan metode penelitian tindakan kelas (CAR). Tindakan kelas yang dilakukan dalam penelitian ini terdiri dari 2 siklus, yang masing-masing siklus terdiri dari 3 kali pertemuan. Langkahlangkah pembelajaran yang dilakukan dalam pertemuan pertama adalah sebagai berikut: (1) guru menjelaskan konsep-konsep dan capaian pembelajaran; (2) siswa membentuk kelompok-kelompok yang masing-masing kelompok terdiri dari 4-5 orang; (3) guru manayangkan rekaman dongeng dengan mempergunakan peralatan elektronik yang telah disediakan; (4) siswa diminta untuk mendiskusikan isi dongeng dalam kelompok masing-masing. Pertemuan kedua (1) Masing-masing kelompok menuliskan hasil diskusinya; (2) Guru memberikan kalimat-lakimat tidak lengkap tentang isi dongeng (3) Siswa melengkapi kalimat-kalimat tersebut dan menyusun menjadi sebuah kesatuan inti dongeng (4) perwakilan kelompok membacakan hasil diskusi ke depan kelas; (5) guru membahas hasil kerja, mengevaluasi dan memberikan umpan balik; (6) guru memberikan tugas rumah untuk latihan. Pertemuan ketiga dilakukan uji kompetensi secara individu.

Dalam evaluasi komptensi hasil belajar, guru menggunakan analisis daya serap dengan tujuan untuk mengetahui hasil maximal/ minimal yang diperoleh siswa, ratarata nilai, jumlah siswa yang memenuhi KKM. Lebih lanjut, guru mengelompokkan siswa yang belum tuntas untuk diberikan remidial yang sebelumnya digali informasi dari individu siswa tentang jenis kesulitan dan latar belakang yang kemudian diberikan tindakan. Disamping hal tersebut guru memberikan jenis pengayaan bagi yang telah memenuhi KKM.

\section{HASIL DAN PEMBAHASAN}

Pada siklus I siswa dibagi dalam kelompok-kelompok diskusi yang masingmasing kelompok terdiri dari 4-5 orang. Media yang dipergunakan dalam kegiatan menyimak pada siklus I yaitu rekaman dongeng dalam format audio. Setelah rekaman diperdengarkan, guru memberikan worksheet berisikan tentang kalimat-kalimat tidak lengkap tentang identifikasi latar, tokoh, dan hal-hal menarik dalam dongeng. Siswa diminta melengkapi kalimat-kalimat tersebut sesuai dengan hasil menyimak dan mendiskusikan dalam kelompok.

Setelah dilakukan observasi selama pelaksanaan pembelajaran terlihat beberapa siswa yang kurang fokus, berbicara dengan teman sebangkunya, saling berbisik. Sehingga seringkali guru harus memperingatkan untuk lebih konsentrasi. Materi dongeng kurang menarik, durasi yang terlalu panjang, serta kualitas audio kurang jernih. Hasil lembar kerja siswa tentang melengkapi kalimat 
banyak yang melenceng dari inti cerita, dan bahkan ada yang tidak mengenal nama tokoh utamanya.

Refleksi dilakukan untuk mengevaluasi tindakan yang telah dilakukan pada siklus I, dengan mengacu pada kerucut pengalaman Edgar Dale agar siswa dapat memperoleh pengalaman yang lebih nyata maka dilakukanlah beberapa perbaikan. yaitu sebagai berikut: (1) rekaman dongeng disertai gambar bergerak (dengar-pandang) dalam bentuk file VCD.; (2) dongeng disesuaikan dengan umur, sehingga menarik minat siswa untuk lebih fokus; (3) penjelasan tentang unsur dongeng lebih detail, serta memberikan contohnya dalam kehidupan nyata; (4) memberikan contoh melengkapi kalimat dengan benar, (5) mengatur kembali tempat duduk siswa. Siswa yang berpotensi kurang memperhatikan diletakkan di depan; (6) pada akhir pelajaran guru memberikan kesimpulan, dan tugas untuk ajang pelatihan.

Setelah dilakukan beberapa perbaikan berdasarkan hasil refleksi siklus I, maka pada kegiatan awal pembelajaran siklus II guru menekankan pada teknik menyimak, bahwa dengan membuat catatan-catatn kecil tentang hal-hal yang penting pada dongeng adalah sangat diperlukan, seperti nama-nama tokoh, seting cerita, aksi-aksi yang dilakukan tokoh, watak dsb. Teknik ini mempermudah siswa dalam membangun ide cerita kembali setelah menyimak. Disamping hal tersebut guru juga menunjukkan bagaimana sikap menyimak yang benar, dengan tidak mengganggu orang lain dan tidak berbicara sendiri, sikap tersebut dijelaskan bahwa kegiatan menyimak adalah penting, selain memahami kelengkapan informasi juga mengekspresikan rasa hormat kepada orang lain yang sedang menyimak. Guru juga memberikan wejangan kepribadian bahwa kebiasaan menyimak dengan baik akan memberikan latihan kepada seseorang untuk saling menghargai dan membentuk kepribadian yang terpuji.

Guru menjelaskan kompetensi yang harus dikuasai siswa dalam pembelajaran menyimak dongeng, siswa memperhatikan dan sesekali menanyakan apa saja yang perlu diperhatikan dalam menyimak dongeng. Guru menjelaskan definisi dongeng, beberapa contoh dongeng serta menjelaskan unsur-unsur dongeng disertai dengan contoh-contoh. Guru juga memberikan contoh amanat yang disampaikan dalam dogeng dengan kehidupan nyata.

Dongeng diputar dengan durasi lebih kurang lima belas menit, siswa diminta untuk mencermati unsur-unsur dongengnya terutama tema dan amanat yang disampaikan dalam dongeng tersebut. Setelah dongeng selesai diputar, pada slide berikutnya muncul pertanyaan tentang dongeng, siswa diberikan waktu 35 menit umtuk menjawab pertanyaan dalam lembar kerja masing-masing.

Dari hasil pengamatan dan evaluasi belajar, maka secara terperinci dapat dilihat perbandingan pada tindakan siklus I dan II sebagai berikut.

\section{A. Proses Belajar Mengajar}

1. Persiapan Guru dalam Mengajar

Berdasarkan 14 item yang diobservasi persiapan guru mengajar pada sisklus I menunjukkan rata-rata cukup, sedangkan pada siklus II menunjukkan ratarata sangat baik. Secara rinci adalah pada siklus I menunjukkan hasil observasi 8 item berkategori cukup dan 6 berkategori baik. Adapun pada siklus II, 5 item menunjukkan kategori baik dan 9 berkategori sangat baik.

Komparasi kedua siklus di atas, ditunjukkan bahwa persiapan guru dalam proses mengajar mengalami peningkatan signifikasi. Ini dapat dilihat di siklus II kategori cukup adalah 0\% bahkan dominansi kategori sangat baik adalah lebih besar.

2. Kegiatan Guru dalam Pelaksanaan Belajar Mengajar

Berdasarkan hasil observasi kegiatan guru dalam pelaksanaan belajar mengajar pada siklus I, dari 28 item 
menunjukkan rata-rata cukup, yaitu 10 item berkategori cukup dan 18 item berkategori baik. Adapun pada siklus II mmenunjukkan rata-rata berkategori baik, yaitu 12 berkategori sangat baik, 11 berkategori baik, dan 5 berkategori cukup.

Sebagaimana kedudukan kedua siklus di atas menunjukkan adanya peningkatan, meskipun belum dapat dikatakan peningkatannya signifikan. Pada siklus I kategori sangat baik adalah $0 \%$ sedangkan pada siklus II diperoleh $42,85 \%$.

3. Kegiatan Guru dalam Menutup Proses Belajar Mengajar

Hasil observasi pada kegiatan guru dalam menutup proses belajar mengajar pada siklus I dan II menunjukkan bahwa 3 item yang diobservasi, pada siklus I, kategori baik 2 item dan kategori cukup 1 item, sedangkan pada siklus II seluruh item yang diobservasi berkategori sangat baik. Ini dapat dikatakan bahwa terjadi peningkatan.yang signifikan.

4. Kegiatan Siswa dalam Persiapan Belajar Hasil observasi pada siklus I tentang kegiatan siswa dalam persiapan belajar menunjukkan bahwa dari 4 item yang diobservasi, ada 1 item berkategori cukup dan 3 item berkategori baik. Adapun pada siklus II seluruh item yang diobservasi adalah berkategori sangat baik.

Siswa dalam persiapan belajar, antara siklus I dan siklus II terjadi perubahan meningkat terutama pada item keadaan mental siswa dalam persiapan proses belajar. Ini dapat dikatakan bahwa $100 \%$ kegiatan siswa dalam persiapan belajar dapat meningkat sangat baik setelah mendapat rujukan dari refleksi pada siklus I.

5. Kegiatan Siswa dalam proses Belajar Mengajar

Berdasarkan hasil observasi dari 11 item pada kegiatan siswa dalam proses belajar menunjukkan rata-rata kategori pada siklus I adalah baik. Adapun rat-rata kategori pada siklus II adalah sangat baik.Pada tabel ini dipaparkan hasil kegiatan siswa dalam proses belajar mengajar pada siklus I dan II. Pada siklus I 1 item berkategori cukup dan 10 item berkategori baik, sedngakan pada siklus II mengalami peningkatan menjadi seluruh item yang diobservasi mendapatkan kategori sangat baik.
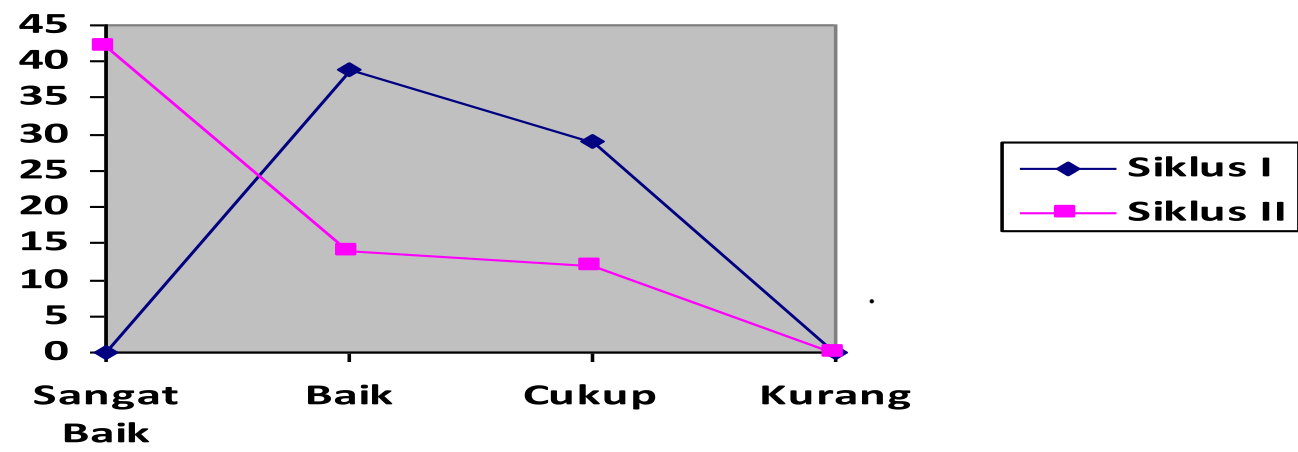

Gambar 1: Hasil Observasi Kegiatan PBM 
Berdasarkan Gambar 1, hasil observasi kegiatan proses belajar menunjukkan bahwa pada siklus I dominansi kategori Baik dengan pencapaian 49, adapun pada siklus II dominansi kategori sangat baik dengan pencapaian nilai 45. Ini dapat diartikan bahwa kategori baik dan cukup pada siklus I $50 \%$ meningkat menjadi kategori sangat baik di siklus II.

\section{B. Penerapan Media Audio Visual dalam Pembelajaran Menyimak}

Hasil observasi penerapan media dalam pembelajaran menyimak dari 4 item terdapat 1 item berkategori kurang dan 3 kategori sangat baik pada siklus I. Adapun pada siklus II 1 item berkategori baik dan 3 kategori sangat baik. Ini menunjukkan bahwa secara garis besar penerapan media audio visual dalam pembelajaran menyimak dapat dikatakan baik. Peningkatan hanya terdapat pada item keragaman materi dongeng yang digunakan oleh guru.
Jika digambarkan dari hasil observasi siklus I dan II dapat diperoleh sajian bahwa media audio visual sangat berperan dalam pembelajaran menyimak. Ini berarti media tersebut telah menjadi alat bantu yang efektif dalam pembelajaran menyimak.

\section{Hasil Evaluasi Menyimak}

1. Analisis Daya Serap Hasil Evaluasi Menyimak Dongeng Siklus I

Berdasarkan hasil analisis daya serap hasil evaluasi menyimak dongeng di siklus I menunjukkan nilai tertinggi adalah 90 yang diperoleh 4 siswa dan nilai terendah adalah 65 yang diperoleh 3 siswa dengan nilai rata-rata 79,19. Ini dapat diartikan jika nilai KKM adalah 75 maka siswa yang belum memenuhi KKM adalah 8 siswa atau 25,80\% dan dapat dikatakan 74,19\% siswa telah memenuhi KKM. Siswa terbesar dengan jumlah 9 anak mendapat nilai 85 . Berikut adalah grafik yang menunjukkan keadaan nilai yang diperoleh siswa pada siklus I.

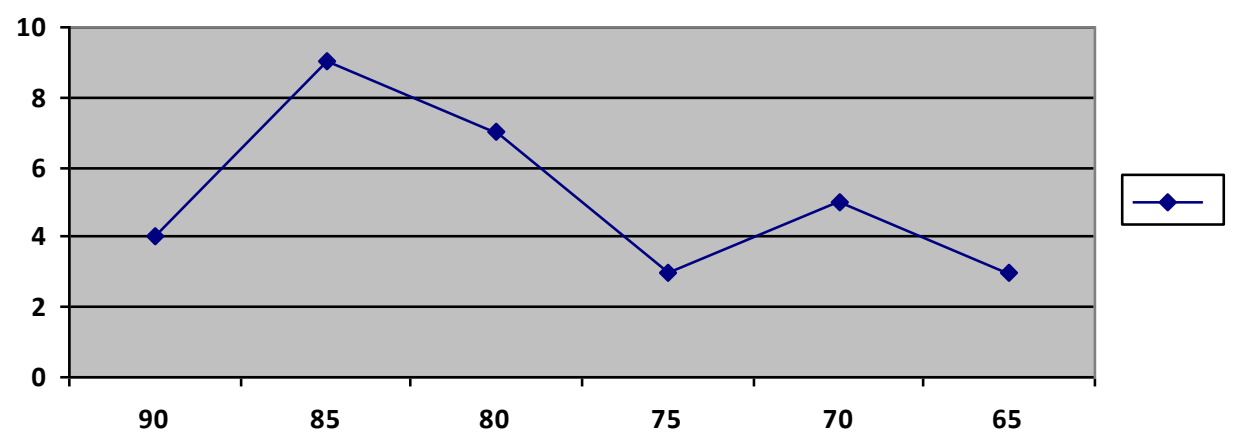

Gambar 2: Hasil Menyimak Siklus I

Analisis daya serap juga merencanakan program remidial bagi siswa yang belum tuntas dan program pengayaan bagi siswa yang sudah tuntas. Hasil wawancara terhadap 8 siswa yang belum tuntas diperoleh hasil jenis kesulitannya adalah rata-rata mereka sulit mengingat tokoh-tokoh yang berperan pada dongeng, menggambarkan seting cerita pada dongeng, dan menarik ide cerita dongeng, serta menemukan nilai moral pada cerita tersebut. Ini dilatorbelakangi oleh tingkat konsentrasi mereka kurang fokus pada dongeng dan ketidak 
tertarikan mereka pada dongeng yang dibawakan oleh guru. Berdasarkan hal tersebut maka dapat diformulakan jenis bantuannya adalah dengan memerintahkan siswa untuk mencatat hal-hal yang penting, seperti nama tokoh, peran tokoh tersebut (antagonis/ protagonis) seting cerita dan ide cerita. Guru juga memberikan kalimat petunjuk kepada siswa untuk melengkapinya. Bagi siswa yang telah memenuhi KKM, guru memberikan tugas menyimak pada cerita-cerita yang berbeda dan berdurasi lebih panjang.
2. Analisis Daya Serap Hasil Evaluasi Menyimak Dongeng Siklus II

Berdasarkan analisis daya serap terhadap hasil evaluasi menyimak dongeng pada siklus II menunjukkan nilai tertinggi adalah 100 yang diperoleh 4 siswa, nilai terendah adalah 75 yang diperoleh 4 siswa, dengan nilai rata-rata adalah 86,12. Ini menunjukkan bahwa jika KKM 75, maka 100\% siswa telah memenuhinya. Siswa terbanyak memperoleh nilai 85 . Berikut adalah grafik keadaan hasil belajar siswa pada keterampilan menyimak dongeng:

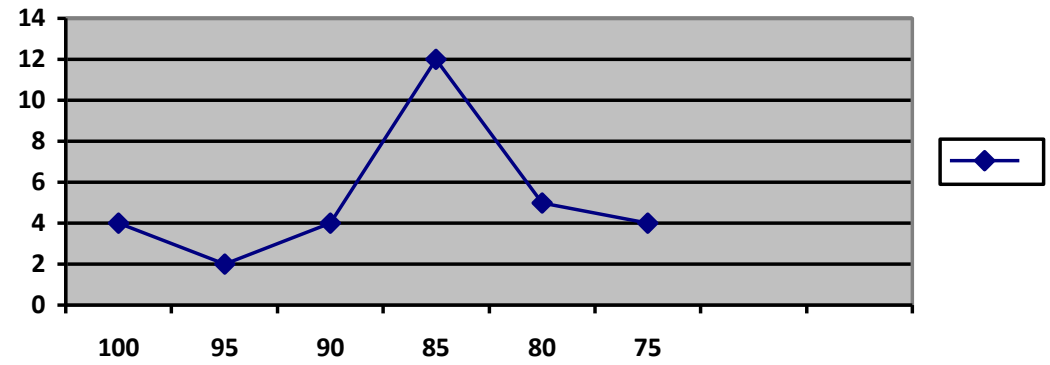

Gambar 3: Analisis Daya Serap Siklus II

Berdasarkan grafik tersebut menunjukkan sudah tidak ada lagi siswa di bawah nilai KKM. Siswa terbanyak adalah pada nilai 85 , ini menunjukkan bahwa sebagian besar siswa mem-peroleh nilai di atas $\mathrm{KKM}$ dengan selisih $\geq 15$ dari nilai batas KKM.
3. Hasil Rekap Evaluasi Keterampilan Menyimak Siklus I dan II

Berdasarkan komparasi siklus I dan siklus II dapat ditunjukkan pada grafik 4 berikut:

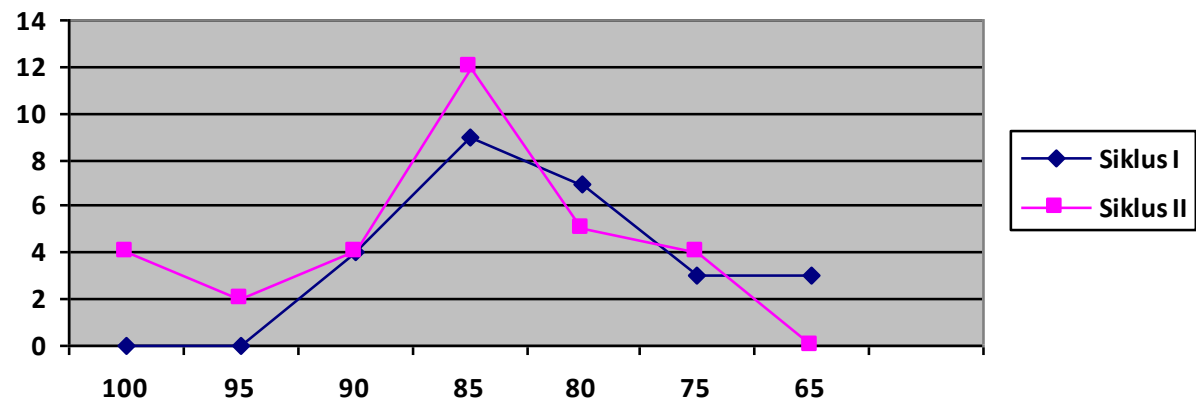

Gambar 4: Hasil Evaluasi Menyimak I dan II

Berdasarkan grafik di atas maka dapat dijelaskan bahwa pada siklus II terjadi peningkatan khusus pada ring nilai 75,85 , 95, dan 100. 


\section{SIMPULAN}

Tidak adanya siswa di bawah nilai KKM dapat disimpulkan bahwa penerapan media audio visual pada komptensi menyimak dongeng dapat meningkatkan hasil belajar siswa kelas VII di SMP Negeri 2 Pakisaji.

Namun demikian sebaik apapun media pembelajaran yang berbasis audio visual utama-nya untuk pembelajaran menyimak dongeng, tidak bisa menggantikan peran pendongeng.

Dongeng akan lebih hidup apabila dituturkan oleh seorang pendongeng, terutama pelibatan emosi dan interaksi langsung antara pendongeng dan pendengarnya.

Perlu kiranya bagi peneliti selanjutnya, untuk menggunakan pendongeng sebagai media pembelajaran menyimak dongeng.

\section{DAFTAR PUSTAKA}

Ahmadi, Mukhsin. 1990. Strategi Belajar Mengajar. Keterampilan Berbahasa dan Apresiasi Sastra. Malang: YA3, FPBS IKIP Malang.

Arsyad, Azhar. 1997. Media Pembelajaran. Jakarta: PT Raja Grafindo Persada.

Brown, J.W., Norberg, K.D. dan Srygley, A.K. 1972. Administering Educational Media: Instructional Technology and Library Services. New York: McGraw-Hill Book Company.

Rivers, Wilga M. dan Tempreley Mary S. 1978. A Practical Guide to The Teaching of English as A Second or Foreign Language. New York: Oxford University Press.

Schramm, Willbur, et all. 1961. Television in The Lives of Our Children. Stanford, Calif: Stanford University Press.

Tarigan, Henry Guntur. 1986. Menyimak Sebagai Suatu Keterampilan Berbahasa. Bandung: Angkasa 